\title{
SOIURI DE MUR DE PERSPECTIVĂ ÎN REPUBLICA MOLDOVA
}

\author{
Lozinschii Mariana, Ciorchină Nina, Pompuș Irina, Grati V. \\ Grădina Botanică Națională (Institut) „,Alexandru Ciubotaru”, Chișinău, Republica Moldova \\ e-mail:diaconm@mail.ru, ninaciorchina@mail.ru
}

Murul arbust fructifer productiv, cu fructe de calitate nutrițională avansată. Fructele de mur dispun de un conținut bogat de compuși naturali prețioși, sunt solicitate pe piață, nu doar în calitate de aliment cu conținut sporit de substanțe nutritive și antioxidante, dar și pentru calitățile gustative, aromă, aspectul atrăgător și apetisant. Principalii cultivatori de mur la nivel mondial rămân a fi cultivatorii din Serbia, Polonia, SUA, Rusia. Cultivarea murului este o activitate relativ nouă în lume, iar în Republica Moldova a început să fie practicată în ultimii 5-6 ani, în mare parte de către pomicultorii amatori în grădinile de pe lângă casă, ulterior la nivel industrial.

În Republica Moldova potrivit estimărilor, sunt peste 150 ha de plantații de mur. Soiurile, varietățile și speciile de mur, după portul creșterii lăstarilor, forma tufei se împart în 3 grupe: erecte (cu creștere dreaptă) semierecte și târâtoare. Majoritatea fermierilor în R. Moldova optează pentru două soiuri fără spini 'Arapaho' și 'Triple Crown'. Ambele sunt de selecție americană, cu creștere erectă și semierectă.

Soiul 'Arapaho' - moderat de viguros, fără spini, productiv. Planta prezintă creștere erectă și compactă. Arbust de talie medie. Necesită susținere pe spalier (2 sârme) sau araci. Înflorește în a doua decadă a lunii mai. Florile albe sunt grupate în inflorescențe. Fructele - formă conică, dimensiuni mari, masa - 6-7 g la coacere, de culoare negricios, lucioase, gust dulcișor, ferme la manipulări și la transportare, se păstrează bine și au aspect comercial atrăgător, coacere uniformă a bacelor, recolta per plantă este de 3-4 kg. Este foarte apreciat de fermieri şi antreprenori având o epoca de coacere timpurie, ultima decadă a lunii iunie până în a doua decadă a lunii iulie (21 zile), este soi timpuriu cu rezistență sporită la geruri $\left(-24^{\circ} \mathrm{C}\right)$, secetă, sensibil la boli.

Soiul 'Triple Crown' - viguros, robust, fără spini, foarte productiv. Planta prezintă creștere semierectă, necesită atașare pe spalieri, sub formă de evantai, formează lăstari lungi (3-6 m) viguroși. Considerat soi autofertil, rodește și în lipsa polenizatorilor. 'Triple Crown' înflorește în a doua jumătate a lunii mai, prima decadă a lunii iunie cu flori de culoare albă. Fructele acestui soi sunt mari, dulci care pot depăși 10-12 g, se caracterizează prin echilibrul bine ajustat al zahărului și acidității. Fructele sunt dulci, aromate, ferme, cu rezistența bună la manipulare și transport. Rodește din abundență, 8,0-10 kg per plantă (peste 15 t fructe/ha) în fiecare an, cu începere din al 2-lea an de la plantare. Epoca de coacere - din a doua decadă a lunii iulie până în prima decadă a lunii septembrie (45-50 zile), este considerat un soi semitimpuriu. Particularităţile agrobiologice - rezistență sporită la îngheț $\left(-25^{\circ} \mathrm{C}\right)$, secetă, boli. În zonele mai reci este indicată protejarea plantelor cu paie sau folie în primii 2 ani de la plantare.

Soiurile 'Arapaho' și 'Triple Crown' sunt cercetate în Laboratorul de Embriologie și Biotehnologie a Grădinei Botanice Națională (Institut) „Alexandru Ciubotaru” (GBNI), materialul săditor de calitate fiind obținut prin micropropagare și multiplicare in vitro, din materialul săditor multiplicat in vitro a fost înființată colecția cu soiuri de mur pe lotul experimental al GBNI. Multiplicarea plantelor prin microtehnici in vitro, asigură obţinerea plantelor sănătoase și viguroase cu o pondere scăzută a bolilor, o rată de multiplicare și rentabilitate economică sporită, pentru sectorul agrar din R. Moldova. Soiurile 'Arapaho' și 'Triple Crown' multiplicate prin vitroculturi au fost utilizate în calitate de material săditor la înființtarea plantaţiilor moderne din raionul Dubăsari, Fălești, Criuleni, Orhei, asigurând lociutorii R. Moldova pe perioada lunilor iulie și septembrie (70 zile) cu fructe proaspete bogate în compuși chimici valoroși și calităţi organoleptice înalt apreciate. 